\title{
Transurethral Resection of the Prostate Syndrome: a Case Report
}

Síndrome pós Ressecção Transuretral da Próstata: Caso Clínico

\author{
Cristina Martins, Pedro Ribeiro \\ Serviço de Medicina Interna, Centro Hospitalar e Universitário de Coimbra, Coimbra, Portugal
}

\begin{abstract}
Transurethral resection of the prostate syndrome is a systemic complication caused by excessive absorption of hypotonic electrolyte-free irrigation fluids, that results in hypervolemia, acute dilutional hyponatremia and consequent neurologic and cardiovascular disturbances, that can range from nausea, vomiting, altered mental status and hypertension, to convulsions, visual disturbances, hypotension, pulmonary edema, cardiac arrest, coma and death. It may occur as early as 15 minutes after resection starts or as late as 24 hours after surgery. The majority of cases published describe the occurrence of the syndrome during surgery, in patients under general anesthesia, being the neurologic manifestations masked and the cardiovascular signs predominant. We describe a case diagnosed in the emergency room, that occurred several hours after surgery and presented mostly with neurologic signs. Immediate and aggressive treatment of acute hyponatremia is a major cornerstone of this syndrome management.
\end{abstract}

Key Words: Acute Hyponatremia; Transurethral Resection of the Prostate; TURP Syndrome

\section{INTRODUCTION}

Transurethral resection of the prostate (TURP) Syndrome is a systemic complication caused by excessive absorption of electrolyte-free irrigation fluids ${ }^{1}$. Though it is called TURP Syndrome, it can occur during other procedures that also require the use of great amounts of irrigating fluids to dilate the mucosal spaces (uretero-renoscopy, percutaneous nephrolithotomy, transcervical resection of endometrium) $)^{2,3}$. Being these fluids hypotonic, their absorption results in hypervolemia and acute dilutional hyponatremia, with consequent neurologic and cardiovascular disturbances, that constitute the TURP Syndrome ${ }^{4,5}$. The clinical spectrum may range from nausea, vomiting, altered mental status and hypertension, to convulsions, visual disturbances, hypotension, pulmonary edema, cardiac arrest, coma and death ${ }^{4,6}$. TURP Syndrome has become a rare event in recent years, with incidence rates between $0.78 \%$ and $1.4 \%{ }^{7}$. Severe TURP syndrome is even rarer, but there are a few cases published, all describing patients that developed a severe form of this syndrome, during surgery, while anesthetized ${ }^{1,4,6,8}$. We report a rare case of a patient that presented to the Emergency Room (ER) with severe manifestations of TURP Syndrome, 24 hours after surgery.

\section{RESUMO}

0 síndrome pós-ressecção transuretral da próstata é uma complicação sistémica deste procedimento, secundário à absorção excessiva de fluidos de irrigação hipotónicos utilizados, com desenvolvimento consequente de hipervolémia e hiponatrémia dilucional aguda que, por sua vez, conduzem a distúrbios neurológicos e cardiovasculares: desde náuseas, vómitos, alterações da consciência e hipertensão arterial, até convulsões, alterações visuais, hipotensão, edema pulmonar agudo, paragem cardiorespiratória, coma e morte. Pode desenvolver-se logo após os primeiros 15 minutos da cirurgia ou até 24 horas da mesma. A maioria dos casos publicados descrevem a ocorrência do síndrome ainda durante a cirurgia, em doentes anestesiados, motivo pelo qual se verifica um predomínio da clínica cardiovascular, estando os sintomas neurológicos mascarados. Os autores descrevem um caso diagnosticado no serviço de urgência, que ocorreu diversas horas após a cirurgia e com manifestações predominantemente neurológicas. 0 tratamento imediato e agressivo da hiponatrémia aguda é primordial na abordagem deste síndrome.

Palavras-chave: Hiponatrémia aguda; Ressecção Transuretral da Próstata; Síndrome Pós-RTU

\section{CLINICAL CASE}

A 76-year-old man, with arterial hypertension and type 2 diabetes, medicated with Telmisartan and Metformin, is referred to the ER, from a private practice (where an emergency support system is nonexistent), with a history of a single tonic-clonic seizure, that lasted approximately 1 minute and had spontaneous resolution. 24 hours before, he had been submitted to a TURP, due to benign hyperplasia, with no peri or post-operative complications. On admission, the patient was afebrile, hemodynamically stable, but confused, somnolent, agitated, with a Glasgow coma scale of 11 (E4M5V2). The remaining neurological and physical exams were normal. A blood gas analysis was performed revealing a sodium (Na) concentration of $115 \mathrm{mmol} / \mathrm{L}$. Being the pre-operative $\mathrm{Na}$ level of $138 \mathrm{mmol} / \mathrm{L}$, a diagnosis of acute severe hyponatremia was made and assumed as the most probable cause of the seizure. A Na correction with hypertonic (3\%) saline was initiated, at a rate of $25 \mathrm{ml} / \mathrm{h}$. Laboratory tests confirmed the results ( $\mathrm{Na} 119 \mathrm{mmol} / \mathrm{L}$ and serum osmolality $253 \mathrm{m0sm} / \mathrm{Kg}$ ) and showed no other major alterations. A head CT and an electroencephalogram (EEG) were still performed, to exclude other potential diagnosis. CT was normal and EEG showed a slow generalized activity, compatible with a diffuse encephalopathy (secondary to the acute hyponatremia). The patient was admitted for observation. Six and twelve hours after the beginning of hypertonic saline, the patient's Na levels were 123 and 125 $\mathrm{mmol} / \mathrm{L}$ (Table 1), respectively, and a progressive improvement of his neurological status was observed with the Na progressive ris- 
Table 1. Temporal variations of relevant analytical parameters

\begin{tabular}{|c|c|c|c|c|c|c|c|c|}
\hline \multicolumn{4}{|c|}{ Admission } & $6 \mathrm{~h}$ & $12 \mathrm{~h}$ & $24 \mathrm{~h}$ & $48 \mathrm{~h}$ & $72 \mathrm{~h}$ \\
\hline \multicolumn{2}{|c|}{ Blood Gas } & \multicolumn{2}{|c|}{ Biochemistry } & \multicolumn{5}{|c|}{ Biochemistry } \\
\hline $\mathrm{pH}$ & 7.40 & Urea & 30 & 24 & 22 & 17 & 16 & 16 \\
\hline pC02 & 35.2 & $\mathrm{Cr}$ & 1.30 & 1.18 & 1.12 & 1.09 & 1.00 & 0.98 \\
\hline p02 & 79.2 & $\mathrm{Na}+$ & 119 & 123 & 125 & 130 & 134 & 137 \\
\hline $\mathrm{HCO}-$ & 21.7 & $K_{+}$ & 3.8 & 4.1 & 4.0 & 4.3 & 3.8 & 3.8 \\
\hline Lactate & 3.5 & Glucose & 221 & 139 & 122 & 100 & 144 & 110 \\
\hline $\mathrm{Na}+$ & 115 & Osm & 253 & 254 & 256 & 273 & 282 & 283 \\
\hline$K_{+}$ & 4.1 & $\mathrm{LDH}$ & 323 & 541 & 411 & 500 & 380 & 190 \\
\hline Glucose & 235 & CPK & 410 & 1519 & 3036 & 2857 & 1365 & 487 \\
\hline
\end{tabular}

ing. No causes of acute hyponatremia were identified, except for the surgical procedure, so a TURP Syndrome was assumed as the most probable cause. The patients Urologist at the private practice later informed that glycine was the irrigation fluid used during the procedure, which reinforced the TURP Syndrome diagnosis. After 72 hours of admission, the patient was discharged, with a serum $\mathrm{Na}$ of $137 \mathrm{mmol} / \mathrm{L}$, a normal neurological exam, and oriented back to his Urologist.

\section{DISCUSSION}

TURP Syndrome is a clinical condition characterized by neurologic and cardiovascular disturbances, that results from excessive absorption of electrolyte-free irrigation fluids, through the opened prostatic venous channels (intravascular) and the perforated prostatic capsule (extravascular) ${ }^{1,4,5}$. The rate of fluid absorption depends on a number of factors, but the average is $20 \mathrm{ml} / \mathrm{min}^{6}$. Given that a regular TURP procedure lasts at least 45-60 minutes, a patient can easily absorb over $1 \mathrm{~L}$ of hypotonic fluid in a small amount of time, leading to hypervolemia, acute dilutional hyponatremia and, ultimately, TURP Syndrome. This may occur as early as 15 minutes after resection starts or as late as 24 hours after the operation 8 . The majority of cases published describe the occurrence of the syndrome during surgery, in patients under general anesthesia, being the neurologic manifestations masked and the cardiovascular signs predominant: usually an unexplained rise in blood pressure followed by a fall associated with refractory bradycardia ${ }^{1,4,6,8}$. We describe a rare case of TURP Syndrome diagnosed in the ER, that occurred several hours after surgery and presented mostly with neurologic signs.

Acute hyponatremia is an electrolyte imbalance capable of causing seizures. Differential diagnosis includes metabolic disturbances, drug toxicity, central nervous system infectious, tumors or trauma, and must be excluded ${ }^{9}$. Potential causes of acute hyponatremia must also be identified: recent thiazides or terlipressin prescription, polydipsia, exercise, colonoscopy preparation, use of methamfetamine, post-TURP ${ }^{9-10}$. Within our case, the overall work-up was unremarkable, except for severe acute hyponatremia, being TURP Syndrome the most logical cause. Treatment depends on the severity and clinical manifestations ${ }^{2}$. Patients with severe manifestations (coma, cardiac arrest, pulmonary edema, severe hypotension, bradycardia) often need intubation, mechanical ventilation and vasopressor support, and should be managed by an intensive care team ${ }^{2-3}$. Patients with moderate symptoms may be treated more conservatively with close monitoring, oxygen and fluid restriction ${ }^{4}$. Despite that, all patients should initiate immediate and aggressive correction of acute hyponatremia with $3 \%$ saline. This will increase serum Na concentration, reduce brain edema and improve symptoms, avoiding their progression ${ }^{5-6}$. The suggested treatment regime is $1.2-2.4 \mathrm{ml} /$ $\mathrm{kg} / \mathrm{h}$. This should produce a rise in serum Na of $1-2 \mathrm{mmol} / \mathrm{h}$. Correction of hyponatremia should not be faster than 1.5-2 $\mathrm{mmol} / \mathrm{L} / \mathrm{h}$ for 3-4 hours then $1 \mathrm{mmol} / \mathrm{L} / \mathrm{h}$ until symptomatic improvement or $\mathrm{Na}$ greater than $125 \mathrm{mmol} / \mathrm{L}$. Maximum rise of Na should not exceed $12 \mathrm{mmol} / \mathrm{L}$ in 24 hours8. In this case, despite the final successful recovery of our patient, we should have been more aggressive with our initial fluid regime (> $25 \mathrm{ml} / \mathrm{h}$ ), since he presented with important neurological manifestations.

The irrigation fluids most commonly used are sorbitol, mannitol and glycine ${ }^{2-3}$.Glycine may contribute to neurologic symptoms in TURP Syndrome, due to direct intravascular toxic effect and indirect effect of metabolites (ammonia) $)^{2,5,8}$. Glycine and ammonia levels can be measured in blood and although their excess does not require a treatment change, it may explain why a specific patient have a more indolent 
clinical course ${ }^{8}$. In this case, we should have measured our patient's glycine and ammonia blood levels.

Even though severe TURP Syndrome is rare, its mortality rate can be as high as $25 \%$. In the setting of acute hyponatremia, presenting in the ER, TURP Syndrome is usually forgotten as a potential cause, due to its rarity, since it is usually diagnosed during surgery or during immediate surgical and anesthetic recovery. However, clinicians should be aware of this possible cause of acute hyponatremia, to allow an adequate management and avoid extensive and inadequate etiological investigations. Besides, in a time where we assist to a rise in private practice facilities, in Europe, possibly lacking holistic medical resources, especially in the emergency field, it is only logical that more cases like this may reach medical professionals in this setting. In the light of this, the authors believe that only through the description of such rare cases can the clinicians be aware of its existence and improve its recognition and adequate management.

\section{REFERENCES}

1. Demirel I, Ozer AB, Bayar MK, Erhan OL. TURP syndrome and severe hyponatremia under general anaesthesia. BMJ Case Reports. 2012; doi:10.1136/bcr-2012006899.

2. Moorthy HK, Philip S. TURP syndrome - current concepts in the pathophysiology and management. Indian J Urol. 2001; 17:97-102.

3. Emmett M, Istre 0, Hahn RG. Hyponatremia following transurethral resection or hysteroscopy. UpToDate 2018. (accessed February 2019). Available from: https:// www.uptodate.com/contents/hyponatremia-following-transurethral-resection-orhysteroscopy.

4. Boukatta B, Sbai H, Messaoudi F, Lafrayiji Z, Bouazzaoui A, Kanjaa N. Transurethral resection of prostate syndrome: report of a case. Pan African Medical Journal. 2013; $14: 14$.

5. Jensen V. Continuing Medical Education: the TURP syndrome. Canadian Journal of Anaesthesia 1991; 38: I/pp90-7.

6. Aziz W, Ather MH. Frequency of Electrolyte Derangement after Transurethral Resection of Prostate: Need for Postoperative Electrolyte Monitoring. Advances in Urology. 2015; doi:10.1155/2015/415735.

7. Hawary A, Mukhtar K, Sinclair A, Pearce I. Transurethral Resection of the Prostate Syndrome: Almost Gone but Not Forgotten. Journal of Endourology. 2009; doi:10.1089/end.2009.0129.

8. Vijayan S. TURP syndrome. Trends in Anaesthesia and Critical Care. 2011; 46-50

9. Spasovski G, Vanholder R, Allolio B, Annane D, Ball S, Bichet D, et al. Clinical practice guideline on diagnosis and treatment of hyponatraemia. Nephrol Dial Transplant. 2014; doi:10.1093/ndt/gfu040.

10. Mount DB. Fluid and Electrolyte Disturbances. In: Kasper DL, Hauser SL, Jameson JL, Fauci AS, Longo DL, Loscalzo J. Harrison's Principles of Internal Medicine 19th Edition. McGraw Hill Education. 2015. 